\title{
I. 血液
}

\section{2. 高齢者の貧血の診断，治療}

\section{東京医科大学老年病科篙崎等優}

Key words : 高齢者, 貧血, 加齢, 二次性貧血, $\mathrm{ACD}$

\section{はじめに}

老年者の貧血診断基準值を便宜上 $\mathrm{Hb} \quad 11.0 \mathrm{~g} /$ $\mathrm{dl}$ 未満に設定すると, 私共の老年科外来患者の 約13\%に負血が発見されている。その原因内訳 は血液疾患または赤血球自体の異常に起因する 原発性貧血は少なく，大部分は貧血を伴い易い 基礎疾患に由来した 2 次性貧血である"。しか し老年者に発生するこれら貧血は複雑な病因・ 病態を呈するのが特徴で診断が困難な場合が少 なくない，老年者の特殊性として，貣血特有の 自覚症状は少なく発見が遅れがちになる場合も 多いが，特に加齢と共に増加の傾向のある悪性 疾患が貧血の䔖に潜在している事もしばしばあ り, 貧血の早期発見及び原因追求は日常の臨床 上重要な作業である。

\section{1. 加齢と造血機能}

加齢に伴って各種臓器の菱縮により, 機能低 下及び予備能の低下が起こるが, 造血臟器も例 外ではない。造血の場である骨䯣にも老年者特 有の変化が明らかに見られてくる．貧血を起こ す基礎疾患を有しない，いわゆる健常老人の末 梢血液においても軽度の負血傾向が出現してく るのは恐らくその結果によるものと考えられて いる.

表は, 当大学病院で1988年より8 年間にわ たって人間ドック受診者の中から収集した65歳 以上の健常老人3583例（男：1590例, 女：1993
例）の末梢血液データの年代別推移”である. 赤血球数, $\mathrm{Hb}$ 值, $\mathrm{Ht}$ 值はそれぞれ何れも加齢 と共にわずかに減少傾向が見られる．平均赤血 球恒数では平均赤血球容積 (MCV) が加齢に よりわずかに増加傾向を示しているが， $\mathrm{MCH}$, MCHCはほぼ一定の值を示している.

思春期以降，造血の中心をなしていた脊椎の 造血䯣は60歳頃より急速に減少し始め特に70歳 を越えると，その面積は半分以下となり，脂肪 髄が大半を占めてくる様になる。この主たる原 因的所見として，加齢による骨䯣内動脈硬化に よって, 造血組織への栄養物質補給の低下によ り造血骨髄の葁縮・形成不全が起こったものと 考えられ, 必然的に造血障害が出現してくると 考えられる. 老年者の造血野/脂肪面積比及び 細胞密度は共に加歯令に伴って減少する傾向を認 め, 一方, 造血幹細胞機能については, BFUE形成能及び赤芽球系前駆細胞（CFU-E）のコ ロニー形成能の観察ではともに高齢者で明らか な低下を認めている．また，老年者の鉄回転で は, 血漿鉄消失速度 $(\mathrm{PIDT} / 2)$ は若年正常者 と差がなかったが, その後の骨髄内造血に際し ての赤血球鉄利用率（\%RCU）は若年者に対 し軽度ではあるが低值を示した。以上の観察結 果より，老年者の骨髄造血動態の特徵は，有核 細胞の減数と骨髄脂肪化による造血野の狭小化 及び細胞密度の低下を主とした造血微小環境の 変化と, 更に造血幹細胞自体の機能低下も加 わって, 造血予備能の低下が惹き起されてくる 
表

\begin{tabular}{|c|c|c|c|c|c|c|}
\hline & \multicolumn{2}{|c|}{ 【赥】[1球数】 $\times 10^{i} / \mathrm{mm}^{3}$} & \multicolumn{2}{|c|}{ 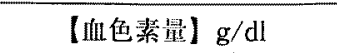 } & \multicolumn{2}{|c|}{ 【へマトクリット䛧】 \% } \\
\hline & 昌 & 女 & 男 & 女 & 男 & 女 \\
\hline 作 踚 & 乘埭 $\pm \mathrm{SD}$ & 婙均 $\pm \mathrm{SD}$ & 平均 $\pm \mathrm{SD}$ & 平均 $\pm \mathrm{SD}$ & 平均 $\pm \mathrm{SD}$ & 平均 $\pm \mathrm{SD}$ \\
\hline$($ 甽性 $=125$, 文性 $=158$ ) & $4.37 \pm 0.51$ & $4.20 \pm 0.48$ & $13.97 \pm 1.40$ & $13.04 \pm 1.39$ & $41.35 \pm 4.23$ & $38.66 \pm 4.02$ \\
\hline$\left(\right.$ 里性 $=\begin{array}{c}70-\sim 74 \\
191, \text { 攵性 }=309 \text { ) }\end{array}$ & $4.36 \pm 0.48$ & $4.12 \pm 0.37$ & $13.98 \pm 1.50$ & $12.86 \pm 1.05$ & $41.38 \pm 4.38$ & $38.19 \pm 3.22$ \\
\hline$($ 男性 $=502$, 女性 $=668$ ) & $4.28 \pm 0.50$ & $4.07 \pm 0.38$ & $13.63 \pm 1.48$ & $12.65 \pm 1.18$ & $40.47 \pm 4.22$ & $37.69 \pm 3.38$ \\
\hline $\begin{array}{c}80 \sim 84 \\
(\text { 男性 }=469, \text { 女性 }=543)\end{array}$ & $4.13 \pm 0.47$ & $3.96 \pm 0.40$ & $13.08 \pm 1.48$ & $12.39 \pm 1.21$ & $38.95 \pm 4.45$ & $36.97 \pm 3.69$ \\
\hline $\begin{array}{c}85 \sim 89 \\
(\text { 男性 }=225, \text { 女性 }=223 \text { ) }\end{array}$ & $4.10 \pm 0.55$ & $3.90 \pm 0.48$ & $12.96 \pm 1.47$ & $12.26 \pm 1.33$ & $38.51 \pm 4.28$ & $36.52 \pm 4.02$ \\
\hline $\begin{array}{c}90 \sim 94 \\
(\text { 哩性 }=62, \text { 女性: }=83)\end{array}$ & $3.91 \pm 0.52$ & $3.78 \pm 0.45$ & $12.57 \pm 1.66$ & $11.95 \pm 1.31$ & $37.28 \pm 4.98$ & $35.77 \pm 3.82$ \\
\hline $\begin{array}{c}95 \sim 99 \\
(\text { 男性 }=16, \text { 文性 }=9)\end{array}$ & $3.83 \pm 0.74$ & $3.59 \pm 0.37$ & $12.47 \pm 1.56$ & $11.46 \pm 0.92$ & $38.98 \pm 6.24$ & $34.19 \pm 2.99$ \\
\hline
\end{tabular}

\begin{tabular}{|c|c|c|c|c|c|c|}
\hline & \multicolumn{2}{|c|}{ 【MCV】 fl } & \multicolumn{2}{|c|}{ 【MCH】 pg } & \multicolumn{2}{|c|}{ 【MCHC】 $\%$} \\
\hline & 昌 & 文 & 男 & 女 & 男 & 女 \\
\hline 年 & 平均 \pm SD & 平均 $\pm \mathrm{SD}$ & 平均 $\pm \mathrm{SD}$ & 平均 $\pm \mathrm{SD}$ & 平均 $\pm \mathrm{SD}$ & 平均 $\pm \mathrm{SD}$ \\
\hline 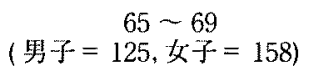 & $94.72 \pm 6.13$ & $92.23 \pm 4.60$ & $31.93 \pm 2.31$ & $31.04 \pm 1.72$ & $33.70 \pm 0.44$ & $33.63 \pm 0.87$ \\
\hline (舁子 $=191$ ，文子 $=309$ ) & $95.39 \pm 5.71$ & $92.87 \pm 4.60$ & $32.11 \pm 2.12$ & $31.27 \pm 1.68$ & $33.68 \pm 0.47$ & $33.67 \pm 0.82$ \\
\hline (男子 $=502$, 好子 $=668$ ) & $94.80 \pm 5.24$ & $92.90 \pm 4.53$ & $31.91 \pm 1.95$ & $31.17 \pm 1.77$ & $33.68 \pm 0.52$ & $33.56 \pm 0.53$ \\
\hline 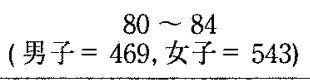 & $94.67 \pm 5.40$ & $93.61 \pm 4.50$ & $31.79 \pm 2.12$ & $31.38 \pm 1.74$ & $33.59 \pm 0.49$ & $33.51 \pm 0.32$ \\
\hline 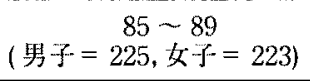 & $94.13 \pm 5.47$ & $93.75 \pm 5.06$ & $31.64 \pm 2.02$ & $31.46 \pm 1.85$ & $33.63 \pm 0.57$ & $33.54 \pm 0.51$ \\
\hline $\begin{array}{c}90 \sim 94 \\
(\text { 贸子 }=62, \text { 女子 }=83 \text { ) }\end{array}$ & $95.34 \pm 4.71$ & $94.86 \pm 5.76$ & $31.98 \pm 1.78$ & $31.70 \pm 2.10$ & $33.57 \pm 0.58$ & $33.44 \pm 0.54$ \\
\hline (男子 $=16$, 文子 $=99$ & $96.88 \pm 4.06$ & $95.18 \pm 4.40$ & $32.62 \pm 1.51$ & $31.68 \pm 1.26$ & $33.68 \pm 0.32$ & $33.31 \pm 0.55$ \\
\hline
\end{tabular}

事である。これらは老年性罆血発現につながる 背景になっていると考えられる。

\section{2. 貧血高撂患者の診察上の留意点}

元来, 貧血の症状は「答白・動悸・めまい」 がtriasとして知られ，老年者でも成人と変わり はない，中でも，皮䖉・粘膜の「答白」は貧血 の主症状であり診断上見落としてはならない重 要な所見である. しかし，老人斑などの色素沈
着により皮膚の蒼白が見つけにくかったり, 結 膜炎の為，結膜の筫血性が隠蔽されていたりす る事も多い。この場合，口腔粘膜で判断するの が信頼性がある．貧血に伴う動悸，息切れなど の自覚症状は, 通常 $\mathrm{Hb} 10 \mathrm{~g} / \mathrm{d} 1$ 以下で見られ, 初めは体動時にのみ出現し, 次第に呼吸困難, 狭心症様症状，更には心不全症状を呈して来る 事があり，老年者にしばしば合併する循環器, 呼吸器疾患に由来するものと誤診し易いので注 
意する「「まい」は全貧血患者の約 $1 / 3$ にみら れ，殆どが非前庭性のdizzinessで，起立時やう つ向いた時などに眼前が暗くなったり，頭がふ らつくタイプが多い.これは負血による酸素運 搬能の低下に加えて, 起立時一過性の心拍出量 低下による脳血流量滅少から惹き起こされる hypoxiaの結果起こるもので, 脳動脈硬化があ ると更に顕著になる。時に情動不安定, 㾰朵様 症状が出現し脳神経系疾患との鑑別を要する事 もある．鉄火乏時の「スプーン状の爪変化」は 特徴的で, 一年以上の長期間, 鉄不足状態が続 いた場合に多い。、角炎，口内炎は鉄久之の特 徵の一つであるが，栄養障害のある老年者にも しばしば見られる。同時に舌乳頭が萎縮して表 面がつるつるになり，塩辛いものが渗みてくる 菱縮性舌炎も認める事が多い.

日常の臨床血液検查を定期的に行っていれ ば，老年者に起こり易い脱水症による血液濃縮 時を除けば，筫血を見逃す事は殆どない。次の 様な場合は䝷血の精密検查を必要とする。

1) 常時 $\mathrm{Hb} 11.0 \mathrm{~g} / \mathrm{dl}$ 末満を呈する場合.

2) $\mathrm{Hb}$ 変動は正常域であっても, 短期間に 急激なHbの低下が見られた場合.

3）赤血球の低下はなくても, 平均赤血球恒 数（MCV, $\mathrm{MCH}, \mathrm{MCHC})$ の何れかに異常值 が見られる場合.

\section{3. 鉄欠乏性貧血}

老年者で最も頻度が高い原発性䝷血である。 原因は主として栄養障害による鉄欠乏と出血に よる鉄の变失で，小球性低色素性負血を呈す。 鉄の吸収には胃酸が重要な働きをするが, 老年 者ではしばしば低酸性の胃炎を認め, 鉄吸収低 下の一因となっている.この筫血を呈する老年 者の過半数は消化管出血によるもので, まず昰 性腫瘍を疑う ${ }^{3 \prime}$. 又, 消炎鎮痛剂常用によるび らん性胃炎 (AGML), 脊椎後彎症による食道 裂孔ヘルニアにも注意が必要である。二次性筫 血との鑑別診断が重要で, 貯蔵鉄を反映する血
清フェリチン值低下を認める事が鑑別点であ る.治療はまず原因疾患の診断・治療を最優先

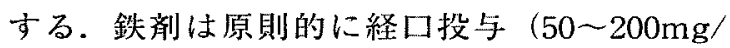
日）するが，副作用の強い時や，経口投与を上 回る需要がある時などは経静脈的投与とする が,この際は鉄過剩予防の為, 予測久乏量を計 算し投与する. 以後,フェリチン值が正常化 (12 $\mathrm{ng} / \mathrm{ml}$ 以上) するまで投与を続ける（ 3 力月間 位).

\section{4. 巨赤芽球性貧血}

抗内因子抗体による悪性筫血と胃切除後数年 しておこる無胃性 $\mathrm{B}_{\mathrm{z} 2}$ 欠乏性貿血が多い。徐々 に発症し高色素性であるため自覚症状が少な く, 赤血球数が100万近くになってはじめて医 療機関を受診する事も稀でない。この筫血は核 酸前駆物質生成の補酵素として作用しているビ 夕ミン $\mathrm{B}_{12}$ または葉酸の欠之による核酸合成障 害に起因して抢り, 赤血球系の他, 白血球系, 血小板系にも成熟障害が及ぶため，骨髄は巨赤 芽球の増加と, 無効造血による過形成像を呈す ることが多い”。このため，末梢血ではしばし ば汎白血球減少症を呈す. 網状赤血球数減少と MCV高值（>120）がよい指標となり，治療は ビタミン $B_{12}$ 非経口投与（1mgを約 2 週間連日 筋肉注射）が不可欠で貧血改善までは，鉄剤の 補給も忘れてはならない. その後, 維持療法 (1 $\mathrm{mg} 2$ を 3 カ月に 1 回筋肉注射) を終生続け る.

葉酸欠乏は老年者ではアルコール性肝障害や 長期寝たきりなどで栄養摂取不良状態や制癌剤 使用時にみられる゙!。葉酸投与で速やかに改善 する。

\section{5. 再生不良性貧血}

骨舗の造血幹細胞或いは造监微小環境が障害 されて, 血球 3 系統にわたって低ないし無形成 骨髄となる造血障害の典型的疾患である。この ため末梢血では汎血球隇少症が認められる，免 
疫異常の関与が明らかなものもあるが多くは原 因不明である，高齢者では本症の䍜患率は若年 者に比して高率である. 治療法は, 蛋白同化ホ ルモン投与, 免疫抑制療法, サイトカイン療法 が試みられている．老年者では骨髄移植の適応 はなく，免疫抑制療法としてはステロイド・パ ルス療法の他，抗胸腺細胞グロブリン (ATG), 抗リンパ球抗体 (ALG) が注目"されている. 造血刺激因子である，G-CSF，EPO，トロンボ ポエチン, IL-3等のサイトカインも多くの研究 があり，老年者でも有効であるとの報告があ る7．その他薬物性骨髄障害による二次性再生 不良性貧血も老年者では少なくない，日常臨床 上軽視できないもので，如何に早く診断し当該 薬㨈を中止するかが重要である。

\section{6. 骨㵦異形成症候群（MDS）}

原因不明の沉血球減少症を主体とし，あらゆ る貧血の治療に反応を示さない骨髄異形成症候 群は近年老年者に増加している，骨髄は再生不 良性䝷血と異なり正〜過形成を呈し，多能性幹 細胞レベルの腫瘍化による，2 系統以上の細胞 形態異常, 機能異常の他, 約半数に染色体異常 を認める。難治性の白血病 (ANLL) 八の移行 が問題視されており，予後因子は芽球数，年齢， 染色体異常，血小板減少などである．治療とし

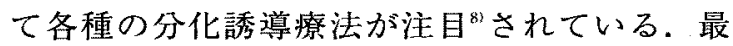
近, $\mathrm{EPO}$ と G-CSFの併用により半数以上の症例 で 3 系統の改善が見られたとの報告"があり注 目を集めている。しかし，G-CSF使用時は白血 化を考慮すべきである。一般に，低リスク群の RA，RARSではビタミンD，A誘導体による治 療が行われている，芽球の増加（末梢血で $5 \%$ 未満，骨䯣で 5 〜 20\%) を伴う予後不良な RAEB，RAEB-Tに対する治療の基本は急性白 血病に準ずるべきであるが，老年者ではAraC の単剂少量投与法 ${ }^{10}$ を選択する. 強力な化学療 法による骨髄不全を避ける事が大切で，あくま でQOLに配慮した治療を心掛ける，専ら輸血
などの支持療法のみに頼らざるを得ない場合も 多い.

\section{2 次性貧血}

2 次性貝血は種々の全身疾患に続発して発生 する貿血の総称である. 老年者には頻度も高く, 筫血全体の $80 \%$ 以上を占めている”。

この筫血の成因は単一ではなく，基礎疾患に より各種の因子が複雑に関与しているため, そ の病態の解釈は単純ではない，筫血の型も基礎 疾患の性質により異なるので，原因疾患の同定 は最も重要である。

原因となり易い基礎疾患としては，(1)悪性腫 瘍, (2)感染症, (3)膠原病, (4)腎疾患, (5)肝疾患, (6)内分泌疾患などが問題であるが，その成因に 関しては不明な点が多い。

本資血の成因として中心をなすものはリウマ 千性疾患, 慢性感染症, 悪性腫瘍に伴う, いわ ゆ ばれるもの"で, 真の貧血の発生機序は不明で あるが，基礎疾患による網内系機能の立進によ り網内系への鉄の抑留が起こり造血細胞への鉄 の動員が障害されているために，へム合成が低 下して筫血が起こったものと考えられている． 主に 3 つの病態を含んでいる.

(1) 鉄代謝障害（鉄吸収障害，血漿鉄の造血 細胞への移入障害, 網内系細胞からの鉄遊離障 害)

(2) 骨骾の造血不全状態（患者マクロファー ジによる赤血球前駆細胞のコロニー形成抑制, EPO産生低下又は反応性低下)

(3) 赤血球寿命の短縮（赤血球膜代謝異常, 網内系機能立進)

これらが互いに複雑に関連しており，通常正 球性正色素性貧血，時に小球性貧血を呈する. 本貧血の臨床検查上の特徽として, 網状赤血球 数は正常で, 血清鉄と総鉄結合能（TIBC）は 共に低下しているが，血清フェリチン值はほほ 正常レベルである点で，鉄久之性筫血との重要 


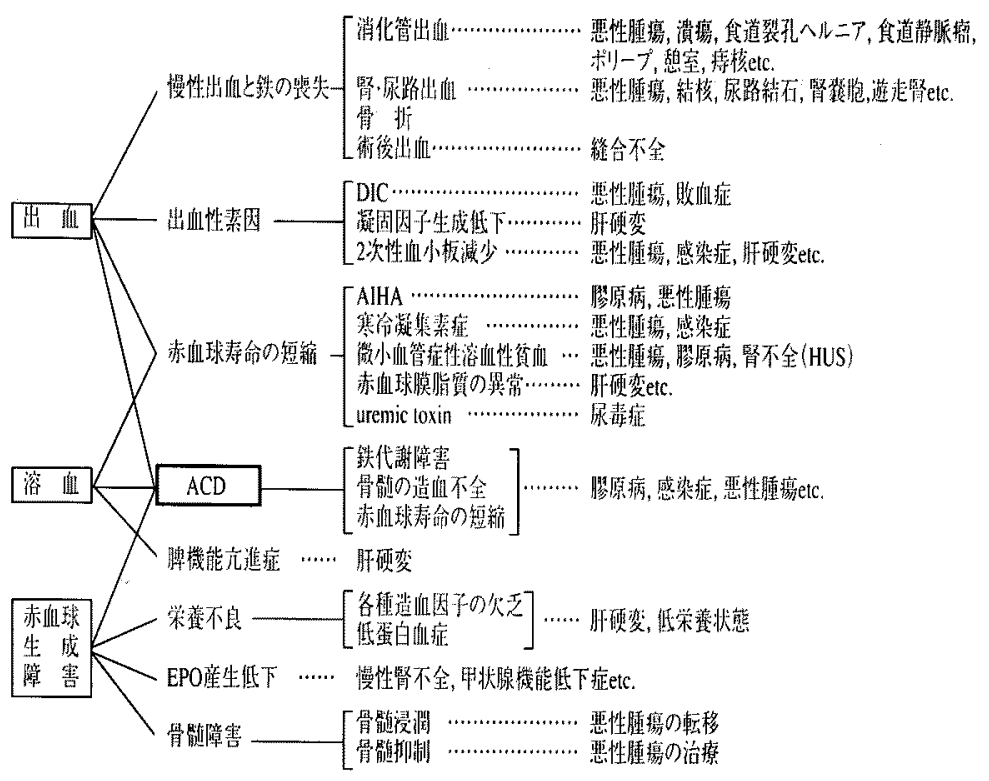

图. 2 次性貧血の三な成因

な鑑別点になっている，従って体内に鉄の欠そ はなく，基礎疾患の改善によって鉄回転が正常 化すれば貧血は改善してくるはずである.

その他の 2 次性貧血の成因は各々の基礎疾患 の病態そのものが筫血発現の原因となってお り，一般の貧血成立機序としての出血，溶血， 赤血球産生低下が互いに組み合わさって発現し たものであり図の様なものが考えられる。

本貧血の共通した特徴としては，基礎疾患が 存在し, 程度は原疾患の重症度に準じ, 多くの 場合，軽〜中等度で慢性に緩徐に出現・進行す るために，俥血症状はないかあっても軽微であ り，通常，正球性正色素性で骨髄を調べても余 り診断の決め手となるような所見は見あたらず 原疾患の治療のみで筫血自体は軽快〜治癔する ことも少なくない。

肝硬変に合併する貧血の発現には出血, 出血 性素因及び溶血と葉酸欠乏が主な因子として関 与している. 出血の大半は食道静脈瘤からのも ので, 脾機能立進症に上る血小板減少も伴い易 いため出血の危険は更に高くなっている.また， アルコール性肝硬変では血中葉酸值が低值を示
し大球性貧血を呈する事当多い.

腎疾患による䝷血は，慢性腎不全にしばしば

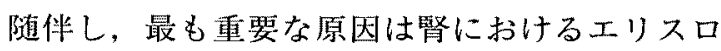
ポエチン（EPO）の産生低下である。䝷血の 程度と腎機能は良く相関'济し，血清クレアチニ ン值が $2 \mathrm{mg} / \mathrm{dl}$ 以上，クレアチニンクリアラン スが $40 \mathrm{ml} / \mathrm{min}$ 以下になると筫血が出現する。

これはBUN, グアニジンなどのuremic toxinに より EPO産生が抑制される事による。今日で は透析に移行する以前の腎性貧血に対しても $\mathrm{EPO}$ 投与が行われている. 副作用として，高 血圧発症が問題点としてあるが，Htの到達目

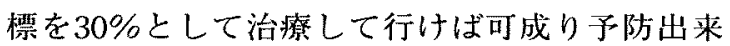
る。

おわりに

日常，臨床の場で高秢者の㙰血は決して少な くない，特に悪性腫演による場合，診断の遅れ が予後に重大な影響を与えるので注意を要す る。しかし䞄血が軽度の場合，自覚症状を欠く ため意外と軽視され，原因不明のまま放置され るか姑息的な治療が行われ，重症になって初め 
て精査が行われる場面をしばしば見受ける。 従って末梢血液データにて変動が見られた時, 原因究明のための積極的な検査を心掛ける注意 が是非とも必要である.

\section{文献}

1）白含貞夫，武 仁：高齢者疾患の湢床像の特徵：貧 Ifl. Geriatric Medicine 32:271, 1994.

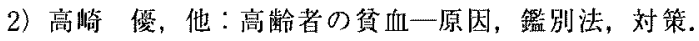
日老会誌 $34: 171,1997$.

3）宮崎 保, 他：老人診療のポイント, 貧血. Medicina $25: 1328,1988$.

4) Handin RI, et al: Blood. Principles and Practice of Hematology. JB Lippincott, Philadelphia, 1995.

5）箖真由美：高龄者䞄血患者の管理，筫血 (野村武夫編). Common disease series $14: 171$, 南江堂, 東京, 1990 .

6) Champlin R, et al : Antilymphocyte globulin treatment in patients with aplastic anemia. $\mathrm{N}$ Engl J Med 308: 113,
1983.

7) 別所正美，他：難治性筫血のエリスロポエチンによる 治療効果. 造血因子 $1 \quad 2: 69,1990$.

8）日野研一郎, 他：難治性貧血の堛床と問題点, 分化誘 渞療法. 臨床血液 $34,3: 283,1993$.

9) Hirashima $K$, et al : Successful treatment of aplastic anemia and refractory anemia by combination therapy with recombinant human granulocyte colony stimulating factor and erythropoietin. Exp Hematol $21: 1080$, 1993.

10) Tilly $\mathrm{H}$, et al:Low-dose cytarabine versus intensive chemotherapy in the treatment of acue nonlymphocytic leukemia in the elderly. J Clin. Oncol 8:272, 1990.

11) Cartwright GE, Lee GR: Anemia of chronic disease. Brit J Hematol $21: 147,1971$.

12) Wintrobe MM: Clinical Hematology, 7th, ed, p701, Lea \& Febiger Philadelphia 1974. 